\title{
Lung Function Evaluation Through Computerized Tomography and 3D Reconstruction of Airways: A Body Mass Index Pilot Study
}

\author{
Evaluación de la Función Pulmonar Mediante Tomografía Computarizada y Reconstrucción 3D \\ de las vías Respiratorias: Estudio Piloto del Índice de Masa Corporal
}

\author{
Rodrigo Muñoz-Cofréé, ${ }^{1,2}$ Aldo Abarca-Ortega ${ }^{3}$; Pablo A. Lizana ${ }^{4}$; \\ Jorge Quiñones Rodríguez ${ }^{5}$; Claudio García-Herrera ${ }^{3}$ \& Mariano del Sol ${ }^{1,2}$
}

\begin{abstract}
MUÑOZ-COFRE, R.; ABARCA-ORTEGA, A.; LIZANA, P.A.; QUIÑONES, J.; GARCÍA-HERRERA, C. \& DEL SOL, M. Lung function evaluation through computerized tomography and 3D reconstruction of airways: A body mass index pilot study. Int. $J$. Morphol., 38(5):1223-1228, 2020.
\end{abstract}

SUMMARY: Obesity is a worldwide epidemic that has become a risk factor for the development of respiratory problems, meaning it is necessary to generate models that assess lung function in obese patients for proper treatment. The objective of this study was to evaluate a model for analyzing respiratory function according to body composition, by analyzing the structure and function of the airways by computed tomography (CT). Lung function and body fat percentage (BF\%) were measured in three male subjects $(25 \pm 6$ years), with different body mass index (BMI; normal, overweight, obese). A third-dimensional (3D) reconstruction of the airways was performed using CT. Trachea, right and left main bronchi and anterior segmental bronchus of the right and left lung were measured. Three measurement points were established for each structure, and the average value of these three points was used for the analysis. An increase in the thickness of the airways wall of the left and right main bronchi and right segmental bronchus was observed as BMI and BF\% increased. The same was observed for the percentage of airway wall area (\%AWA) and airway resistance in the main and segmental bronchi. The proposed 3D reconstruction model and the three-point analysis simplified image assessment and allowed to observe the problems caused by obesity in lung function.

KEYWORDS: Obesity; Body composition; Airways resistance; Airway anatomy; Airway wall area.

\section{INTRODUCTION}

The World Health Organization (WHO) defines obesity as "an abnormal or excessive accumulation of fat that can be harmful to health." In 2016 more than 1.9 billion adults were overweight, of which 650 million were obese (WHO, 2020). Chile is not the exception, as reports indicate that there is a high prevalence of obesity throughout the entire life cycle of Chileans (Lizana et al., 2016; Lizana et al., 2018; MuñozCofré et al., 2019; Lizana et al., 2020). The last 2016-2017 National Health Survey revealed that obesity is an increasing problem, as it went from $50 \%$ of the population in 20092010 to $70 \%$ in 2016-2017 (Ministerio de Salud, 2019).

Obesity is considered a risk factor for numerous chronic diseases, and contributes to the prevalence of multiple respiratory diseases (Zammit et al., 2010; Lin \& Lin, 2012; Littleton et al., 2012; Mafort et al., 2016; Parraguez et al., 2018). Weight overload would affect the elastic properties of the rib cage, generating a decrease in lung volume and capacity, and it is believed that this is associated with changes in the elastic resistance of the thorax, parenchyma and airways (Lin \& Lin; Steier et al., 2014). The thickness of the chest wall would therefore contribute to reducing lung compliance and airway conductance (Talaminos Barroso et al., 2018), favoring an increase in its resistance (Littleton et al.; Dattani et al., 2016; Parraguez et al.).

To determine if a person is obese, different measurements are used. However, there is still a lack of

\footnotetext{
${ }^{1}$ Centro de Excelencia en Estudios Morfológicos y Quirúrgicos, Universidad de La Frontera, Temuco, Chile.

${ }^{2}$ Doctorado en Ciencias Morfológicas, Universidad de La Frontera, Temuco, Chile.

${ }^{3}$ Departamento de Ingeniería Mecánica de la Universidad de Santiago de Chile, Santiago, Chile.

${ }^{4}$ Laboratory of Morphological Sciences, Instituto de Biología, Pontificia Universidad Católica de Valparaíso, Valparaíso, Chile.

${ }^{5}$ Unidad de Imagenología, Clínica de la Universidad Católica del Maule, Talca, Chile.
} 
MUÑOZ-COFRE, R.; ABARCA-ORTEGA, A.; LIZANA, P.A.; QUIÑONES, J.; GARCÍA-HERRERA, C. \& DEL SOL, M. Lung function evaluation through computerized tomography and 3D reconstruction of airways: A body mass index pilot study. Int. J. Morphol., 38(5):1223-1228, 2020.

consensus among researchers on a single accepted "reference" approach to quantify fat mass in vivo, this being a controversial point when evaluating obesity (Heymsfield et al., 2015). Two of the measurements used are the body mass index (BMI) and body fat percentage (BF\%), both with contradictory information associated with respiratory disorders, as significant associations have been found with one or both measurements (Canoy et al., 2004; Chen et al., 2007; Parraguez et al.; Rodríguez et al., 2019).

One of the respiratory problems associated with obesity is increased resistance of the airways due to thickening of the bronchial wall (Canoy et al.; Chen et al.; Parraguez et al.; Rodríguez et al., 2019). Observation of these changes is important to understand obesity pathogenesis and the effect of possible therapeutic interventions in obese patients. Thus, the combined use of digital images and third-dimensional (3D) reconstruction software allows non-invasive quantification of the airways, to investigate structural changes in a timely manner and initiate early treatment to prevent definitive airway remodeling (Diaz et al., 2016). Therefore, the purpose of this research was to evaluate a model to characterize airway structure and function, which would allow this function to be correlated with body composition.

\section{MATERIAL AND METHOD}

Participants. Three participants with different nutritional status (BMI, categorized as normal weight $18.5 \mathrm{~kg} / \mathrm{m}^{2} \leq \mathrm{BMI}$ $<25 \mathrm{~kg} / \mathrm{m}^{2}$, overweight $25 \mathrm{~kg} / \mathrm{m}^{2} \leq \mathrm{BMI}<30 \mathrm{~kg} / \mathrm{m}^{2}$, and obese $\left.\mathrm{BMI} \geq 30 \mathrm{~kg} / \mathrm{m}^{2}\right)$ were recruited. The inclusion criteria were to be male (women were not included due to the differences in the anatomy of the airways of men and women; Dominelli et al., 2018) and to be over 18 years of age. Exclusion criteria were clinical evidence of chronic respiratory disease (forced expiratory volume in 1 second $<80 \%$ of predicted), active smoking, morphological changes in the chest or spine. All participants signed an informed consent form previously endorsed by the Ethics Committee of the University of Santiago de Chile (014-2020).

Anthropometry. Height was measured with a SECA® anthropometer (model 220, Hamburg, Germany) and body mass was measured with a SECA ${ }^{\circledR}$ balance (model 840, Hamburg, Germany) (Iinternational Society for the Advancement of Kineanthopometry, 2001). Then, BMI was calculated with the formula height in meters/kilograms squared. Body fat was estimated from skinfold thickness (Lange Skinfold Caliper®, Beta Technology, Santa Cruz California, USA) and the equations of Durnin and Womersley (Durnin \& Womersley, 1974).
Ventilatory volumes and pressures. Tests were performed on a Mediagraphics body plethysmograph (Platinum Elite Model DL® St. Paul, Minnesota, USA). Measurements were taken according to the regulations of the American Thorax Society (ATS). The mouthpiece was adjusted to the height of the oral cavity and the subject was asked to block the facial musculature with both hands. Subsequently, the cabin was closed and the subject was instructed to perform four ventilations at tidal volume. Then, the subject was instructed to "gasp softly" trying to move volumes of 50 to $60 \mathrm{~mL}$ while blocking his cheeks with the ends of his fingers to avoid pressure fluctuation in the oral cavity. The gasping rate should have been close to 60 per minute $(1 \mathrm{~Hz})$ (American Thoracic Society \& European Respiratory Society, 2002; Miller et al., 2005).

Chest computed tomography (CT) scan. The lung image was taken with a 16-MDCT scanner (Sensation 16, Siemens Healthcare) according to the low-dose acquisition protocol and without contrast medium. The protocol was spiral at $130 \mathrm{kV}$. A CARE DOSE 4D® dose modulation system was used, providing a reference dose of about $60 \mathrm{mAs}, 0.6 \mathrm{sec}$ rotation time, $16 \times 1.2 \mathrm{~mm}$ collimation, $350 \mathrm{~mm}$ FOV, 1.5 $\mathrm{mm}$ cut thickness and $0.7 \mathrm{~mm}$ cut increase. Image recording was performed during inspiration at full lung capacity. The effective radiation dose was less than $0.8 \mathrm{mSv}$ and the images were reconstructed to a $512 \times 512$-pixel matrix with a soft medium core (B30s) for the mediastinal window images and a defined filter (B70s) for the images of pulmonary window (Xie et al., 2014).

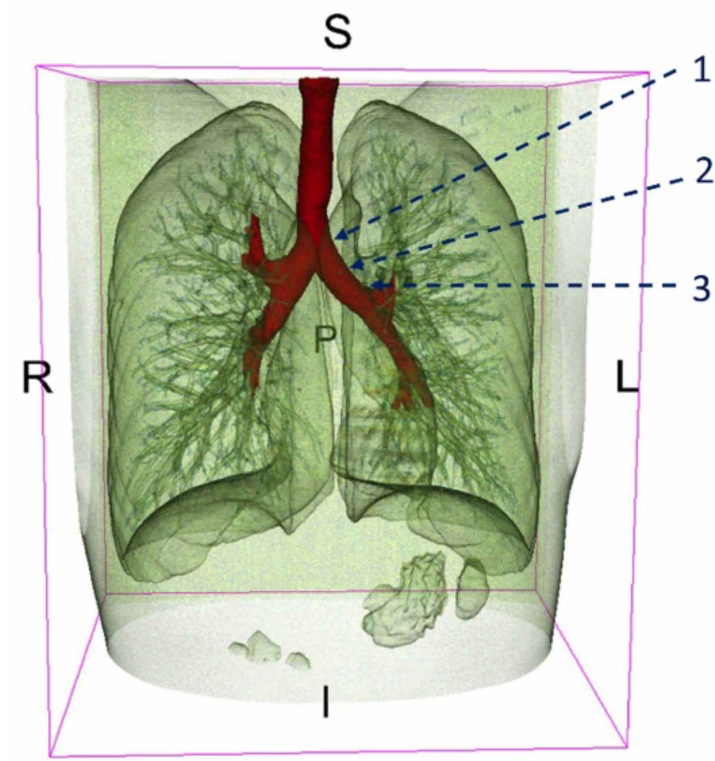

Fig. 1. 3D chest reconstruction, the airways are highlighted in red, the numbers correspond to the measurement points. 1, two millimeters below the start of the main bronchus; 2 , midpoint of main bronchus; 3 , two millimeters above the bifurcation of the main bronchus 
Airway measurements and image analysis. Measurements were made of the trachea, right and left main bronchi and anterior segmental bronchus of the upper lobe of the right and left lung. Three measurement points were established for each structure: $2 \mathrm{~mm}$ below the lower limit of the structure, $2 \mathrm{~mm}$ above the upper limit of the structure, and the midpoint between both limits. The average value of these three points was used for the analyzes (Fig. I). 3D reconstruction of the images was performed with the open source 3D Slicer software (Slicer V4.10.0) and the VTK (Visualization toolkit) software, performing a manual segmentation of the areas to be measured (Díaz et al., 2014). This technique allows measurements to be made in different perpendicular planes on the objectives, so real results are obtained for each sector independent of its inclination, orientation or direction. Three quantitative measurements were made: diameter of the lumen of the trachea, main bronchi and segmental bronchus; wall thickness, lumen diameter, and wall (total diameter) of the structures noted above (Fig. 2).

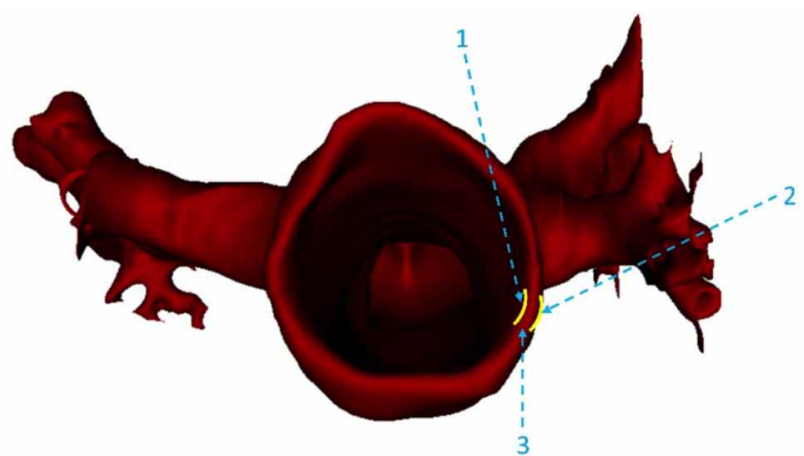

Fig. 2. Schematic cross section, where measurements of airway diameters were made. 1 inner edge; 2 outer edge; 3 airway wall.

\section{RESULTS}

The sample had an average age of $22.66 \pm 0.57$ years, and the participants represented the conditions of normal weight, overweight and obesity (Table I). All three subjects showed normal range lung function (Table II). Table III

Table I. Anthropometric characteristics of the study sample, stratified by weight status.

\begin{tabular}{lcccc}
\hline & Normal weight & Overweight & Obese & Mean \pm SD \\
\hline Age (years) & 23 & 23 & 22 & $22.66 \pm 0.57$ \\
Weight $(\mathrm{kg})$ & 56.2 & 83 & 95.5 & $78.23 \pm 20.07$ \\
Height $(\mathrm{m})$ & 1.69 & 1.74 & 1.79 & $1.74 \pm 0.05$ \\
BMI $\left(\mathrm{kg} / \mathrm{m}^{2}\right)$ & 19.67 & 27.41 & 29.80 & $25.62 \pm 5.29$ \\
Body Fat (\%) & 16.55 & 22.65 & 22.88 & $20.69 \pm 3.59$ \\
Bicipital skinfold (mm) & 3 & 8 & 6 & $5.66 \pm 2.51$ \\
Triceps skinfold (mm) & 7 & 11 & 13 & $10.33 \pm 3.05$ \\
Subscapular skinfold (mm) & 11 & 18 & 19 & $16 \pm 4.35$ \\
Suprail iac skinfold (mm) & 20.33 & 31 & 31.3 & $27.54 \pm 6.24$ \\
\hline
\end{tabular}

SD: standard deviation; BMI: body mass index (kilograms divided by the square of the height in meters).

Table II. Description of the pulmonary function, stratified by weight status.

\begin{tabular}{lcccc}
\hline & Normal weight & Overweight & Obese & Mean \pm SD \\
\hline IC $(\mathrm{L})$ & 2.56 & 3.8 & 2.45 & $2.93 \pm 0.74$ \\
ER V (L) & 1.75 & 1.58 & 0.68 & $1.33 \pm 0.57$ \\
RV (L) & 3.26 & 1.37 & 1.19 & $1.94 \pm 1.14$ \\
FRC (L) & 5.01 & 2.95 & 1.87 & $3.27 \pm 1.59$ \\
TLC (L) & 758 & 6.75 & 4.32 & $6.21 \pm 1.69$ \\
RAW $\left(\mathrm{cmH}_{2} \mathrm{O} / \mathrm{L} / \mathrm{s}\right)$ & 0.47 & 0.87 & 2.23 & $1.19 \pm 0.92$ \\
$\mathrm{GAW}\left(\mathrm{L} / \mathrm{s}_{\mathrm{cmH}} \mathrm{O}\right)$ & 2.12 & 1.15 & 0.45 & $1.24 \pm 0.83$ \\
sRAW $\left(\mathrm{cmH}_{2} \mathrm{O}^{*} \mathrm{~s}\right)$ & 2.46 & 2.93 & 5.34 & $3.57 \pm 1.54$ \\
$\mathrm{SGAW}\left(1 / \mathrm{cmH}_{2} \mathrm{O}^{*} \mathrm{~s}\right)$ & 0.41 & 0.34 & 0.19 & $0.31 \pm 0.11$ \\
$\mathrm{MIP}\left(-\mathrm{cmH}_{2} \mathrm{O}\right)$ & 99 & 156 & 68 & $107.66 \pm 44.63$ \\
$\mathrm{MEP}\left(\mathrm{cmH}_{2} \mathrm{O}\right)$ & 90 & 117 & 71 & $92.66 \pm 23.11$ \\
\hline
\end{tabular}

SD: standard deviation; MIP: maximum inspiratory pressure; $\mathrm{cmH}_{2} \mathrm{O}$ : centimeters of water; MEP: maximum expiratory pressure; IC: inspiratory capacity; VRE: expiratory reserve volume; RV: residual volume; FRC: functional residual capacity; TLC: total lung capacity; RAW: airway resistance; GAW: airway conductance; sRAW: specific airway resistance; sGAW: specific airway conductance; $\mathrm{cmH}_{2} \mathrm{O} / \mathrm{L} / \mathrm{s}$ : centimeters of water divided liters divided seconds; $\mathrm{L} / \mathrm{s} / \mathrm{cmH}_{2} \mathrm{O}$ : liters divided seconds divided centimeters of water; $\mathrm{cmH}_{2} \mathrm{O}^{*} \mathrm{~s}$ : centimeters of water per second; $1 / \mathrm{cmH}_{2} \mathrm{O} * \mathrm{~s}$ : one divided centimeters of water per second. 
MUÑOZ-COFRE, R.; ABARCA-ORTEGA, A.; LIZANA, P.A.; QUIÑONES, J.; GARCÍA-HERRERA, C. \& DEL SOL, M. Lung function evaluation through computerized tomography and 3D reconstruction of airways: A body mass index pilot study. Int. J. Morphol., 38(5):1223-1228, 2020.

shows the airway wall thickness (AWT) values and the percentage of airway wall area (\%AWA). Image analysis revealed that there was a parallel increase in $\mathrm{BMI}$ and $\mathrm{BF} \%$ in relation to AWT of the right and left main bronchus and right segmental bronchus. The same was observed for the $\%$ AWA of the main and segmental bronchi (Table III).

Table III. Airway morphology characteristics, stratified by weight status.

\begin{tabular}{|c|c|c|c|c|c|c|c|c|}
\hline \multirow{5}{*}{$\begin{array}{c}\text { Normal weight } \\
\text { Overweight }\end{array}$} & \multicolumn{4}{|c|}{ Airway wall thickness (mm) } & \multicolumn{4}{|c|}{ Percentage of airway wall area } \\
\hline & \multicolumn{2}{|c|}{ Main bronchus } & \multicolumn{2}{|c|}{ secondary bronchus } & \multicolumn{2}{|c|}{ Main bronchus } & \multicolumn{2}{|c|}{ Secondary bronchus } \\
\hline & Right & Left & Right & Left & Right & Left & Right & Left \\
\hline & 4.4 & 43 & 4.9 & 3.5 & 19.5 & 23.3 & 24.6 & 25.2 \\
\hline & 3.9 & 5.0 & 35 & 4.6 & 16.2 & 26.2 & 27.3 & 25.5 \\
\hline Obese & 5.6 & 6.4 & 55 & 5.7 & 21.9 & 31.2 & 42.1 & 31.5 \\
\hline Mean \pm SD & $4.63 \pm 0.87$ & $5.23 \pm 1.09$ & $4.63 \pm 1.02$ & $4.61 \pm 1.10$ & $19.23 \pm 2.86$ & $26.92 \pm 3.99$ & $31.33 \pm 9.42$ & $27.46 \pm 3.55$ \\
\hline
\end{tabular}

SD: standard deviation.

\section{DISCUSSION}

The purpose of this study was to evaluate a model to measure the structure and function of the airways and to analyze its relationship with body composition. The results indicate that the presented methodology is viable, since our findings coincide with those described by Mahadev et al. (2003); that is, the greater the AWT, the greater the resistance to air flow (Mahadev et al.). Additionally, it was observed that the higher the BMI and BF\%, the greater the AWT, a situation consistent with that reported by Barton et al. (2016).

Regarding body composition and airway resistance, a significant increase in resistance has been reported in obese subjects compared to normal-weight subjects (Salome et al., 2008). This phenomenon was attributed to the decrease in functional residual capacity (FRC), which would generate a reduction in airway diameter due to the loss of traction of the lung parenchyma; and to the compression of the body mass on the chest wall. Taken together, these phenomena would alter lung compliance (Salome et al.). This coincides with the results of this study, where there was an increase in airway resistance parallel to the increase in BMI and BF\% (Table III). Similarly, Barton et al. found correlation between BMI and \%AWA $(\mathrm{r}=0.55, \mathrm{p}<0.001)$ in patients with obstructive airway phenotypes and HIV infection. However, it is important to highlight that a healthy sample is being compared against one with diagnosed pathologies, which generates a research gap in relation to normal subjects and how these results could contribute to the generation of reference values in this area.

Although the structural biometric parameters obtained in this study are similar to those used in morphology, such as total bronchial area, wall area, internal area (lumen) and AWT (Díaz et al., Washko et al., 2012), the results found here differ from those reported in the literature. When Washko et al. evaluated the wall area, lumen area and total bronchial area through CT in 5,179 smoking subjects and 92 non-smokers, a \%APVA of 57 was found in the nonsmoking group, which is higher than the average observed in this study (38.12\%) (Washko et al.). These differences would be explained by the different age ranges, as the airways present age-specific variations (Mehran et al., 2018); but also by the method used, as in this study we considered the average of three different anatomical points of the airways, whereas Washko et al. carried out a single measurement, a relevant factor given the anatomical and physiological variability of the airways. For instance, the luminal diameter can be dynamically modified with changes in intraluminal pressure, the trachea narrows slightly as it progresses into the carina, and the main bronchi differ in direction, length, and diameter from each other (Minnich et al., 2007; Mehran et al., 2018 ). These characteristics could alter airway resistance; therefore, in this specific case, making representative measurements of the reconstructed anatomical structure is clinically relevant.

Moreover, Al-Alwan et al. (2014) wanted to check whether lung function in obese patients with and without asthma would change after weight loss due to bariatric surgery. The authors observed a significant decrease in airway resistance after weight loss in obese non-asthmatic subjects. From this, it was proposed that the load of adipose tissue on the upper abdomen and thorax produces significant changes in lung compliance, compared to deposits located only on the thorax. Therefore, subjects with the same BMI would have a different fat distribution and different respiratory disorders (Al-Alwan et al.).

In this context, the evidence indicates that android patterns negatively influence lung volumes and capacities. On the other hand, the android patterns would generate a decrease in respiratory flows due to an increase in airway resistance (Bates et al., 2016). In this sense, future research should include more precise instruments such as electrical 
bioimpedance or X-ray absorptiometry to assess $\mathrm{BF} \%$ and adipose tissue distribution (Werner et al., 2009). The aim should be to validate clinical tools that help locate adipose tissue to improve accessibility and diagnostic of this type of disorder.

One of the limitations of this study is the number of participants evaluated; because of this, the results are only descriptive of the overall process. However, the objective of this study was the implementation of a method of evaluating airway structure by means of high-end 3D reconstruction of medical images and which allowed to correlate the function of the airways by plethysmography with body composition. 3D reconstruction through medical images, such as CT, also allows numerical computational biomechanical analysis based on simulations of lung function using the finite element method (Tawhai et al., 2004; Werner et al., 2008, 2009).

\section{CONCLUSIONS}

The 3D reconstruction method made it possible to measure the airways, and the use of the average of three different anatomical points behaved as reported in the literature. It was observed that as the BMI and BF\% increased, so did the thickness of the bronchial wall and the resistance of the airways. Finally, to improve this model and complement the data obtained, other methods must be included to determine the specific location of adipose tissue and its distribution.

MUÑOZ-COFRE, R.; ABARCA-ORTEGA,A.; LIZANA, P.A.; QUIÑONES, J.; GARCÍA-HERRERA, C. \& DEL SOL, M. Evaluación de la función pulmonar mediante tomografía computarizada y reconstrucción 3D de las vías respiratorias: Estudio piloto del índice de masa corporal. Int. J. Morphol., 38(5):1223-1228, 2020.

RESUMEN: La obesidad es una epidemia mundial, la que se ha transformado en un factor de riesgo en el desarrollo problemas respiratorios. Al respecto, generar modelos de evaluación de la función pulmonar en pacientes obesos es relevante para su adecuado tratamiento. El objetivo de este trabajo fue evaluar un modelo de la estructura y función de las vías aéreas (VA) con tomografía computarizada (TC) que permita analizar su comportamiento de acuerdo a la composición corporal. A tres sujetos de sexo masculino ( $25 \pm 6$ años), de distinto índice de masa corporal (IMC; normal, sobrepeso, obeso), se les midió función pulmonar y porcentaje de grasa corporal (\% GC). A través de TC se realizó una reconstrucción en tercera dimensión (3D) de las VA. Se realizaron mediciones de las VA de la tráquea, bronquios principales derecho e izquierdo y bronquio segmentario anterior del pulmón derecho e izquierdo. Para cada estructura se establecieron tres puntos de medición, el valor utilizado para los análisis fue el promedio de estos tres puntos. En los tres participantes se observó un aumento del grosor de la pared de las vías aéreas de los bronquios principal derecho e izquierdo y bronquio segmentario derecho a medida que aumenta el IMC y el \% GC. Por otra parte, el porcentaje de área de la pared de las vías aéreas (\% APVA) se comportó de la misma manera para ambos bronquios principales y segmentarios. La resistencia de las vías aéreas (RVA), tanto general como específica, aumentó en paralelo con el \% APVA en los bronquios principales y segmentarios. A través de un modelo de reconstrucción 3D de la estructura de la VA por TC, evaluando tres puntos, se pudo observar los problemas que trae la obesidad a la función pulmonar simplificando el análisis de imagen.

PALABRAS CLAVE: Obesidad, composición corporal, resistencia de las vías aéreas, anatomía de las vías aéreas, área de la pared de las vías aéreas.

\section{ACKNOWLEDGEMENTS}

DICYT from University of Santiago de Chile. CONICYT PFCHA/doctorate, Chile scholarships/2019cel00011051 of A A-O.

\section{REFERENCES}

Al-Alwan, A.; Bates, J. H.; Chapman, D. G.; Kaminsky, D. A.; DeSarno, M. J.; Irvin, C. G. \& Dixon, A. E. The nonallergic asthma of obesity. A matter of distal lung compliance. Am. J. Respir. Crit. Care. Med., 189(12):1494-502, 2014.

American Thoracic Society \&European Respiratory Society. ATS/ERS Statement on respiratory muscle testing. Am. J. Respir. Crit. Care. Med., 166(4):518-624, 2002.

Barton, J. H.; Ireland, A.; Fitzpatrick, M.; Kessinger, C.; Camp, D.; Weinman, R.; McMahon, D.; Leader, J. K.; Holguin, F.; Wenzel, S. E.; Morris, A. \& Gingo, M. R. Adiposity influences airway wall thickness and the asthma phenotype of HIV-associated obstructive lung disease: a cross-sectional study. BMC Pulm. Med., 16(1):111, 2016.

Bates, J. H. Physiological Mechanisms of Airway Hyperresponsiveness in Obese Asthma. Am. J. Respir. Cell. Mol. Biol., 54(5):618-23, 2016.

Canoy, D.; Luben, R.; Welch, A.; Bingham, S.; Wareham, N.; Day, N. \& Khaw, K. T. Abdominal obesity and respiratory function in men and women in the EPIC-Norfolk Study, United Kingdom. Am. J. Epidemiol., 159(12):1140-9, 2004.

Chen, Y.; Rennie, D.; Cormier, Y. F. \& Dosman, J. Waist circumference is associated with pulmonary function in normal-weight, overweight, and obese subjects. Am. J. Clin. Nutr., 85(1):35-9, 2007.

Dattani, R. S.; Swerner, C. B.; Stradling, J. R. \& Manuel, A. R. Exploratory study into the effect of abdominal mass loading on airways resistance and ventilatory failure. BMJ Open Respir. Res., 3(1):e000138, 2016.

Diaz, A. A.; Estépar, R. S. \& Washko, G. R. Computed Tomographic Airway Morphology in Chronic Obstructive Pulmonary Disease. Remodeling or Innate Anatomy?. Ann. Am. Thorac. Soc., 13(1):4-9, 2016. 
Diaz, A. A.; Zhou, L.; Young, T. P.; McDonald, M. L.; Harmouche, R.; Ross, J. C.; Estepar, R.; Wouters, E. F.; Coxson, H. O.; MacNee, W.; Rennard, S.; Maltais, F.; Kinney, G. L.; Hokanson, J. E.; Washko, G. R. \& ECLIP$\mathrm{SE}$ investigators. Chest $\mathrm{CT}$ measures of muscle and adipose tissue in COPD: gender-based differences in content and in relationships with blood biomarkers. Acad. Radiol., 21(10):1255-61, 2014.

Dominelli, P. B.; Ripoll, J. G.; Cross, T. J.; Baker, S. E.; Wiggins, C. C.; Welch, B. T. \& Joyner, M. J. Sex differences in large conducting airway anatomy. J. Appl. Physiol. (1985), 125(3):960-5, 2018.

Heymsfield, S. B.; Ebbeling, C. B.; Zheng, J.; Pietrobelli, A.; Strauss, B. J.; Silva, A. M. \& Ludwig, D. S. Multi-component molecular-level body composition reference methods: evolving concepts and future directions. Obes. Rev., 16(4):282-94, 2015.

International Society for the Advancement of Kinanthropometry. International Standards for Anthroponetric Assessement. Underdale, ISAK, 2001. Disponible en http://www.ceap.br/material/MAT17032011184632.pdf.

Lin, C. K. \& Lin, C. C. Work of breathing and respiratory drive in obesity. Respirology, 17(3):402-11, 2012.

Littleton, S. W. Impact of obesity on respiratory function. Respirology, 17(1): 43-9, 2012.

Lizana, P. A.; Cisternas-Vallejos, P.; Araya, L.; Aguilera, F. \& Mora, M. Obesity, body fat distribution, and Physical Activity in School-age Children: An Urban and Rural Comparison in Valparaíso, Chile. Biomed. Environ. Sci., 29(11):834-9, 2016.

Lizana, P. A.; González, S.; Lera, L. \& Leyton, B. Association between body composition, somatotype and socioeconomic status in Chilean children and adolescents at different school levels. J. Biosc. Sci., 50(1):53-69, 2018.

Lizana, P. A.; Vega-Fernandez, G. \& Lera, L. Association Between Chronic Health Conditions and Quality of Life in Rural Teachers. Front. Psychol., 10: 2898, 2020.

Mafort, T. T.; Rufino, R.; Costa, C. H. \& Lopes, A. J. Obesity: systemic and pulmonary complications, biochemical abnormalities, and impairment of lung function. Multidiscip. Respir. Med., 11:28, 2016.

Mahadev, S.; Salome, C. M.; Berend, N. \& King, G. G. The effect of low lung volume on airway function in obesity. Respir. Physiol. Neurobiol., 188(2):192-9, 2003.

Mehran, R. J. Fundamental and Practical Aspects of Airway Anatomy: From Glottis to Segmental Bronchus. Thorac. Surg. Clin., 28(2):117-25, 2018.

Miller, M. R.; Hankinson, J.; Brusasco, V.; Burgos, F.; Casaburi, R.; Coates, A.; Crapo, R.; Enright, P.; Van der Grinten, C. P.; Gustafsson, P.; Jensen, R.; Johnson, D. C., MacIntyre, N.; McKay, R.; Navajas, D.; Pedersen, O. F.; Pellegrino, R.; Viegi, G.; Wanger, J. \& ATS/ERS Task Force. Standardisation of spirometry. Eur. Respir. J., 26(2):319-38, 2005.

Minnich, D. J. \& Mathisen, D. J. Anatomy of the trachea, carina, and bronchi. Thorac. Surg. Clin., 17(4):571-85, 2007.

Ministerio de Salud (MINSAL). Encuesta Nacional de Salud 2016-2017: Primeros resultados. Santiago de Chile, Ministerio de Salud, Gobierno de Chile, 2017. Disponible en https://www.minsal.cl/wp-content/uploads/ 2017/11/ENS-2016-17_PRIMEROS-RESULTADOS.pdf.

Muñoz Cofré, R.; del Sol, M.; Medina González, P.; Escobar Inostroza, J.; Lizana, P. A.; Conei, D. \& Escobar Cabello, M. Relation among body mass index, waist-hip ratio, and pulmonary functional residual capacity in normal weight versus obese Chilean children: A cross-sectional study. Arch. Argent. Pediatr.,117(4):230-6, 2019.

Parraguez Arévalo, A.; Rojas Navarro, F.; Ruz Céspedes, M.; Medina González, P.; Escobar Cabello, M. \& Muñoz Cofré, R. The impact of obesity on specific airway resistance and conductance among schoolchildren. Arch. Argent. Pediatr., 116(2):e227-e233, 2018.

Rodríguez, S.; Donoso, D.; Sánchez, E.; Muñoz, R.; Conei, D.; del Sol, M. \& Escobar, M. Uso del Índice de Masa Corporal y Porcentaje de Grasa Corporal en el Análisis de la Función Pulmonar. Int. J. Morphol., 37(2):592-9, 2019

Salome, C. M.; Munoz, P. A.; Berend, N.; Thorpe, C. W.; Schachter, L. M. \& King, G. G. Effect of obesity on breathlessness and airway responsiveness to methacholine in non-asthmatic subjects. Int. J. Obes. (Lond)., 32(3):502-9, 2008.
Steier, J.; Lunt, A.; Hart, N.; Polkey, M. I. \& Moxham, J. Observational study of the effect of obesity on lung volumes. Thorax, 69(8):752-9, 2014.

Talaminos Barroso, A.; Márquez Martín, E.; Roa Romero, L. M. \& Ortega Ruiz, F. Factors Affecting Lung Function: A Review of the Literature. Factores que afectan a la función pulmonar: una revisión bibliográfica. Arch. Bronconeumol., 54(6):327-32, 2018.

Tawhai, M. H.; Hunter, P.; Tschirren, J.; Reinhardt, J.; McLennan, G. \& Hoffman, E. A. CT-based geometry analysis and finite element models of the human and ovine bronchial tree. J. Appl. Physiol. (1985), 97(6):2310-21, 2004.

Washko, G. R.; Parraga, G. \& Coxson, H. O. Quantitative pulmonary imaging using computed tomography and magnetic resonance imaging. Respirology, 17(3):432-44, 2012.

Werner, R.; Ehrhardt, J.; Schmidt, R. \& Handels, H. Modeling respiratory lung motion: a biophysical approach using finite element methods. Proc. SPIE., 6916:1-11, 2008.

Werner, R.; Ehrhardt, J.; Schmidt, R. \& Handels, H. Patient-specific finite element modeling of respiratory lung motion using $4 \mathrm{D}$ CT image data. Med. Phys., 36(5):1500-11, 2009.

World Health Organization (WHO). Obesity and overweight. Geneva, Worls Health. Disponible en http://www.who.int/news-room/fact-sheets/detail/ obesity-and-overweight.

Xie, X.; Dijkstra, A. E.; Vonk, J. M.; Oudkerk, M.; Vliegenthart, R. \& Groen, H. J. Chronic respiratory symptoms associated with airway wall thickening measured by thin-slice low-dose CT. AJR. Am. J. Roentgenol., 203(4):W383-W390, 2014.

Zammit, C.; Liddicoat, H.; Moonsie, I. \& Makker, H. Obesity and respiratory diseases. Int. J. Gen. Med., 3:335-43, 2010.

Corresponding author:

Rodrigo Muñoz Cofré, MSc.

Center of Excellence in Morphological and Surgical Sciences (CEMyQ)

Avenida Francisco Salazar \# 01145

Universidad de La Frontera

Temuco

CHILE

Email: b.munoz13@ufromail.cl

Received: 07-02-2020

Accepted: 14-04-2020 